\title{
Occurrence of antibodies against Leptospira spp. in donkeys of São Paulo state
}

\section{Ocorrência de anticorpos contra Leptospira spp.}

em asininos no estado de São Paulo

\author{
Maria do Carmo Custódio de Souza Hunold Lara ${ }^{1 *}$ (D), Eliana Monteforte Cassaro Villalobos' ${ }^{10}$, \\ Elenice Maria Sequetin Cunha ${ }^{1}$ (D), José Victor de Oliveira ${ }^{2} \mathbb{D}$, Vanessa Castro ${ }^{1}$ (D), Alessandra Figueiredo \\ de Castro Nassar' (D), Lília Márcia Paulin Silva' (D), Liria Hiromi Okuda' (D), Adriana Hellmeister de Campos \\ Nogueira Romaldini' ${ }^{1}$, Mariana Sequetin Cunha ${ }^{3}$ (D), Eduardo Carvalho Marques ${ }^{1}$ (D), Enio Mori ${ }^{4}$ (D)
}

\begin{abstract}
Among the diseases that affect equines, bacterial diseases play an important role from a health and economic point of view, especially leptospirosis and brucellosis. The study aimed to provide information on the occurrence of anti-Leptospira spp. and anti-Brucella abortus antibodies in donkeys of São Paulo state. We found a frequency of 62.4\% (53/85) antibodies against Leptospira spp. The donkeys were not seropositive for Brucella spp.
\end{abstract}

KEYWORDS: donkeys; serology; leptospirosis; brucellosis.
RESUMO: Entre as doenças que acometem os equídeos, as enfermidades bacterianas assumem um papel importante do ponto de vista sanitário e econômico, destacando-se a leptospirose e a brucelose. O estudo teve como objetivo fornecer informaçóes sobre a ocorrência de anticorpos anti-Leptospira spp. e anti-Brucella abortus em jumentos no estado de São Paulo. Estimou-se que 62,4\% (53/85) dos animais apresentavam anticorpos anti-Leptospira spp. Os jumentos estudados não foram sororreagentes contra a Brucella spp.

PALAVRAS-CHAVE: jumentos; sorologia; leptospirose; brucelose. 
Leptospirosis is an infectious disease caused by spirochete bacteria of the genus Leptospira, which affects domestic and wild animals, with humans at the end of the chain of transmission. Wild animals, mammals (rodents, herbivores, insectivores, carnivores), birds, reptiles, and amphibians have been reported as carriers or reservoirs of Leptospira for humans and domestic animals. They are distributed worldwide, being highly prevalent in tropical and sub-tropical countries, where the temperature and humidity conditions favor their development. Acute leptospirosis outbreaks in equids are poorly documented, even though the disease is known worldwide. Cases of uveitis and relapsing iridocyclitis culminating in blindness have been linked to serological results for serovar Pomona. In Brazil, few reports have described isolations, such as the study by GIORGI et al. (1981), which revealed the first isolation of Leptospira spp. from aborted horse fetus, probably due to serovar Icterohaemorrhagiae. Serological surveys have been carried out in populations of donkeys, and the three performed in Brazil showed that the incidence of animals seropositive to Leptospira spp. varied from 25.53 to $85 \%$ (BEZERRA et al., 2010; OLIVEIRA FILHO et al., 2014; SHIMABUKURO et al., 2001).

In equids, Brucella abortus causes brucellosis, which mainly leads to suboccipital or interscapular bursitis, called "bad withers." It can also result in abortion in the last trimester of pregnancy and compromise reproductive and osteoarticular systems or have no symptoms. Equids are considered accidental hosts of the disease and usually contract it from other species such as cattle and pigs. Bad withers caused by brucellosis poses a public health risk, so infected animals should be euthanized. Several countries conducted serological surveys for antibodies to Brucella spp. in populations of donkeys, with incidence levels ranging from 0 to $40 \%$. However, most studies found low levels of positivity (less than 10\%) (ABO-SHEHADA, 2009; ACOSTA-GONZÁLEZ et al., 2006; DORNELES et al., 2013; GIDEL et al., 1974; SADIQ et al., 2013; TEL et al., 2011).

Donkeys have notable importance in the production of hybrid animals. The male donkey breeds with a horse mare to produce mules and donkeys, which are used as work animals on farms because of their hardiness and stamina. For this reason, these animals should be free from contagious diseases.

Given the importance of donkeys to humans as a source of draft power for different activities, the objective of this study was to provide information on the occurrence of antibodies to bacterial agents affecting donkeys of São Paulo state, Brazil.

Between 2009 and 2010, a total of 85 serum samples were collected from healthy donkeys from 5 properties located in Pirassununga, Barretos, Colina, and Araçatuba, São Paulo state, Brazil. Female donkeys had continuous access to pasture, while stallions were housed in stalls. At the time of collection, no animal had a history of clinical signs of brucellosis and leptospirosis.
For the study of brucellosis, we used the buffered acidified antigen test. In this test, an antigen suspension was diluted to $8 \%$ in a buffer solution, $\mathrm{pH} 3.65$. Acidification enhances IgG1 agglutination (which is lower at neutral $\mathrm{pH}$ ), destroys nonspecific agglutinins, and reduces IgM reactivity, thereby decreasing cross-reactivity with other etiological agents. This test is qualitative and ideal for screening herds.

Leptospirosis was determined by the microscopic seroagglutination technique with live antigens, used to measure agglutinin levels of all serum samples. Live cultures of Leptospira spp. 24 serovars were kept in liquid-modified EMJH medium, with 7 - 10 days of growth, free from contamination and autoagglutination, and with an approximate density of 100 to 200 microorganisms per microscopic field, at 400X magnification. The reaction was performed in polystyrene 96-well microtiter plates, using $50 \mu \mathrm{L}$ of serum diluted 1:50 initially in Sorensen's phosphate-buffered saline ( $\mathrm{pH} 7.4)$ and adding $50 \mu \mathrm{L}$ of antigen, yielding an initial dilution of $1: 100$. To determine the final titer of antileptospiral agglutinins in each serum, 2-fold serial dilutions were prepared in Sorensen's phosphate buffered saline ( $\mathrm{pH}$ 7.4). The microplates were incubated at $28-30^{\circ} \mathrm{C}$ for three hours, followed by reading with dry dark-field microscopy, at 100X magnification, revealing the formation of clumps. The serum titer was considered the reciprocal of the highest dilution that showed 50\% agglutinated Leptospira.

We found leptospirosis antibodies against the following serovars: Icterohaemorrhagiae in $35(41.2 \%)$ animals, Pomona in 4 (4.7\%), Grippotyphosa in 26 (30.6\%), Australis in $2(2.4 \%)$, Autumnalis in $2(2.4 \%)$, Shermani in $4(4.7 \%)$ Canicola in $1(1.2 \%)$, Wolffi in $1(1.2 \%)$, Hardjo in 18 (21.2\%), Bratislava in $23(21.2 \%)$, Bataviae in $1(1.2 \%)$, and Copenhageni in $3(3.5 \%)$, with the total of seropositive animals being $62.4 \%(53 / 85)$.The results suggest that leptospirosis also affects donkeys, as reported in several papers, and should be better studied because of its important zoonosis and for the close relationship between humans and this animal species. The high incidence observed in this study may be explained by the fact that these animals have a low livestock value in the study area. Therefore, donkeys are not kept in stables and have greater access to pastures (flooded and watery areas), close to the excretions of other reservoir species for leptospirosis, for example, rodents and cattle (OLIVEIRA FILHO et al., 2014).

Positivity for the serovars Icterohaemorrhagiae and Grippotyphosa suggest direct or indirect contact with excretions of rodents and other wildlife since they are natural hosts of these serovars (LANGONI et al., 2004; HASHIMOTO et al., 2007; CHIARELI et al., 2008; OLIVEIRA FILHO et al., 2014).

Cattle generally act as reservoirs for the serovar Hardjo (ARAÚJO, 2010). Equids are regarded as accidental hosts for this serovar (CHIARELI et al., 2008). This study considered 
that the animals that were positive for this serovar were likely bred in close contact with cattle.

The serovar Bratislava also showed a high incidence in clinically asymptomatic animals. This result corroborates those reported by various authors, suggesting that horses can serve as a reservoir for this serovar (KITSON-PIGGOT; PRESCOTT, 1987; BARWICK et al., 1998; AGUIAR et al., 2008; BÅVERUD et al., 2009).

The absence of animals seropositive for Brucella spp. among the donkeys in this study indicates that infection was not present or the prevalence was low in this population. Although the donkeys demonstrated an infection development similar to that observed in horses, it is difficult to assess the true impact of infection by Brucella spp. in this species or their importance in the epidemiology of brucellosis (DORNELES et al., 2013). The direct comparison between frequencies of seropositive animals found in serological surveys in Brazil and different countries and the results obtained in this study is useful, mainly due to differences in observational studies, serological tests, diagnostic cut-offs, sample size, and representativeness.

Positive serological results for Leptospira spp. suggest that donkeys could be an active or potential reservoir for this disease and they may be transmissible to other domestic livestock. In addition, donkeys might constitute a dormant threat for the direct infection of humans (leptospirosis).

\section{ACKNOWLEDGMENTS}

Grant \#2008/52048-9, São Paulo Research Foundation (Fapesp).

|| || |||||||||||||||||||||||||||||||||||||||||||||||||||||||||||||||||||||||||||||||||||||||||||||||||||||||||||||||||||||||||||||||||||||||||||||||||||||||||||||||||||||||||||||||||||||||||||||||||||||||||||||||||||||||||||||||||||||||||||||||||||||| REFERENCES

ABO-SHEHADA, M.N. Seroprevalence of Brucella species in equids in Jordan. Veterinary Record, v. 165, p.267-268, 2009. https://doi.org/10.1136/vr.165.9.267

ACOSTA-GONZÁLEZ, R.I.; GONZÁLEZ-REYES, I.; FLORESGUTIÉRREZ, G.H. Prevalence of Brucella abortus antibodies in equines of a tropical region of Mexico. Canadian Journal of Veterinary Research, v.70, n.4, p.302-304, 2006.

AGUIAR, D.M.; CAVALCANTE, G.T.; LARA M.C.C.S.H.; VILLALOBOS, E.M.C.; CUNHA, E.M.S.; OKUDA, L.H.; DE STÉFANO, E.; NASSAR, A.F.C.; SOUZA, G.O.; VASCONCELLOS, S.A.; LABRUNA, M.B.; CAMARGO, L.M.A.; GENNARI, S.M. Prevalência de anticorpos contra agentes virais e bacterianos em eqüídeos do Município de Monte Negro, Rondônia, Amazônia Ocidental Brasileira. Brazilian Journal of Veterinary Research and Animal Science, v.45, n.4, p.269-276, 2008. ttps://doi.org/10.11606/issn.1678-4456. bjvras.2008.26685

ARAÚJO, B.M. Soroepidemiologia da infecção por Leptospira spp. em bovinos, equídeos, caninos e trabalhadores rurais em assentamento no município de Aragominas, Tocantins, Brasil. 2010. 112 f. Thesis (Doutorado em Ciência Animal) - Escola de Veterinária, Universidade Federal de Goiás, Goiânia, 2010.

BARWICK, R.S.; MOHAMMED, H.O.; ATWILL, E.R.; MCDONOUGH, P.L.; WHITE, M.E. The prevalence of equine leptospirosis in New York State. Journal of Equine Science, v.9, n.4, p. 1 19-124, 1998.

BÅVERUD, V.; GUNNARSSON, A.; ENGVALL, E.O.; FRANZÉN, P.; EGENVALL, A. Leptospira seroprevalence and associations between seropositivity, clinical disease and host factors in horses. Acta Veterinaria Scandinavica, v.51, p. 15, 2009. https:// doi.org/10.1186/1751-0147-51-15

BEZERRA, D.C.; CHAVES, N.P.; GUERRA, P.C.; PEREIRA, H.M.; SANTOS, H.P. Pesquisa de aglutininas antileptospira em soros sanguíneos de asininos (Equus asinus) e de condutores de veículos de tração animal na cidade de São Luís, MA, Brasil. Ciência Animal Brasileira, v. 1 1, n.4, p.931-937, 2010. https:// doi.org/10.5216/cab.v1 1 i 4.9233

CHIARELI, D.; MOREIRA, E.C.; GUTIÉRREZ, H.O.D.; RODRIGUES, R.O.; MARCELINO, A.P.; MENESES, J.N.C, ALMEIDA, V.M.A. Frequência de aglutininas anti-Leptospira interrogans em equídeos, em Minas Gerais, 2003/2004. Arquivo Brasileiro de Medicina Veterinária e Zootecnia, v.60, n.6, p.1-4, 2008. https://doi. org/10.1590/SO102-09352008000600043

DORNELES, E.M.S.; FERNANDES, L.G.; SANTANA, J.A.; FREITAS, F.J.C.; LIMA, J.M.; BARROS, I.O.; SAKAMOTO, S.M.; HEINEMANN, M.B.; LAGE, A.P. Anti-Brucella abortus antibodies in free-ranging equids from Mossoró, Rio Grande do Norte, Brazil. Semina: Ciências Agrárias, v.34, n.3, p.1281-1286, 2013. https://doi. org/10.5433/1679-0359.2013v34n3p1281

GIDEL, R.; ALBERT, J.P.; LE MAO, G.; RETIF, M. La brucellose en Afrique occidentale et son incidence sur La santé publique. Résultats de dix enquêtes épidémiologiques effectuées em Côte d'ivoire, Haute-Volta et Niger de 1970 à 1973. Revue D 'Elevage et Medecine Veterinaire des Pays Tropicaux, v.27, p.403-418, 1974. https://doi.org/10.19182/remvt.7937

GIORGI, W.; TERUYA, J.M.; MACRUZ, R.; GENOVEZ, M.E.; SILVA, A.S. Leptospirose em equinos: inquérito sorológico e isolamento de Leptospira icterohaemorrhagiae de feto equino abortado. Biológico, v.47, n.2, p.47-53, 1981.

HASHIMOTO, V.Y.; GONÇALVES, D.D.; SILVA, F.G.; OLIVEIRA, R.C.; ALAVES, L.A.; REICHMANN, P.; MULLER, E.E; FREITAS, J.C. Occurrence of antibodies against Leptospira spp. in horses of the urban area of Londrina, Paraná, Brazil. Revista do Instituto de Medicina Tropical, v.49, n.5, p.327-330, 2007. https://doi. org/10.1590/S0036-46652007000500010 
KITSON-PIGGOT, A.W.; PRESCOTT, J.F. Leptospirosis in horses in Ontario. Canadian Journal of Veterinary Research, v.51, n.4, p.448-451, 1987.

LANGONI, H.; DA SILVA, A.V.; PEZERICO, S.B.; DE LIMA, V.Y. Antileptospirose agglutinins in equine sera, from São Paulo, Goias, and Mato Grosso do Sul, Brazil, 1996-2001. Journal of Venomous Animals and Toxins Including Tropical Diseases, v. 10, n.3, p.207-218, 2004. https://doi.org/10.1590/S1678-91992004000300003

OLIVEIRA FILHO, R.B.; MALTA, K.C.; OLIVEIRA, J.M.B.; SANTANA, V.L.A.; HARROP, M.H.V.; STIPP, D.T.; PINHEIRO JUNIOR, J.W. Epidemiological analysis of Leptospira spp infection in equids from the Brejo Paraibano Microregion of Brazil. Journal of Equine Veterinary Science, v.34, n.3, p. 407-414, 2014. https://doi.org/10.1016/j.jevs.2013.08.001
SADIQ, M.A.; TIJJANI, A.N.; AUWAL, M.S.; MUSTAPHA, A.-R.; GULANI, I. Serological Prevalence of Brucellosis among Donkeys (Equus asinus) in Some Local Government Areas of Yobe State, Nigeria. Journal of Equine Veterinary Science, v.33, n.3, p.150-154, 2013. https://doi.org/10.1016/j.jevs.2012.05.071

SHIMABUKURO, F.H.; MORAES-SILVA, E.; MENDONÇA, A.O.; CERQUEIRA, E.J.L.; ARAÚJO, W.N.; SARKIS, D.T.; SHERLOCK, I.; LANGONI, H. Aspectos soroepidemiológicos da leptospirose em eqüídeos, dos Municípios de Jacobina e Jequié, Bahia. Ciência Veterinária nos Trópicos, v.4, n.2-3, p.274-280, 2001.

TEL, O.U.; ARSERIM, N.B.; KESKIN, O. Seroprevalence of equine brucellosis in southeast Turkey. Kafkas Universitesi Veteriner Fakultesi Dergisi Journal, v.22, p.181-183, 2011. 